Eur. J. Clin. Chem. Clin. Biochem.

Vol. 31, 1993, pp. 159-163

(C) 1993 Walter de Gruyter \& Co.

Berlin - New York

\title{
Ektachem Slides Overestimate Serum Albumin in Patients with Nephrotic Syndrome
}

\author{
By F. K. Gorus and M. Van Blerk \\ Laboratorium Klinische Chemie, Akademisch Ziekenhuis, Vrije Universiteit Brussel, Brussels, Belgium
}

(Received November 9, 1992)

Summary: In a non-selected patient population $(n=140)$, serum albumin concentrations obtained with Ektachem slides were very significantly correlated with results determined with serum protein electrophoresis on Olympus Hite 200. In 7 patients with nephrotic syndrome, however, no such correlation existed, concentrations on Ektachem being 20 to $200 \%$ higher (up to $16 \mathrm{~g} / 1$ difference). In other samples, albumin concentrations on Ektachem were $10 \mathrm{~g} / 1$ lower. Between-method differences appeared most closely correlated with the sum of $\alpha_{1}$ - and $\alpha_{2}$-globulins as determined by serum protein electrophoresis. Immunonephelometric determination of various serum proteins demonstrated that haptoglobin concentrations most closely paralleled the observed between-method differences.

\section{Introduction}

Bromcresol green and, to a lesser degree, bromcresol purple are widely used "chromogens" for the rapid colorimetric determination of albumin in serum $(1-6)$. In spite of its lower specificity, bromcresol green has often been preferred over bromcresol purple in commercial reagents (7-9). Arguments against bromcresol purple include:

1) underestimation of albumin in cases of renal insufficiency (10) and obstructive jaundice (11);

2) lesser precision and sensitivity of bromcresol purple assays because of the 2 times lower molar absorptivity for the bromcresol purple-albumin dye complex as compared with bromcresol greenalbumin (9);

3) difficulties in the standardization and monitoring of bromcresol purple-based assays with non-human fluids, due to the fact that bromcresol purple - unlike bromcresol green - does not strongly bind to bovine serum albumin, often present in calibrators and quality control materials (9).

On the other hand, bromcresol green suffers from a more pronounced reactivity with various globulins (5). These undesirable side-reactions proceed, how- ever, at a much slower rate. Consequently, by making spectrophotometric readings shortly after the addition of reagent, the specificity of bromcresol green assays for albumin is safeguarded, keeping it at a level comparable to that of bromcresol purple-assays (12-15).

Bromcresol green has been incorporated into Ektachem multilayer film elements (Eastman Kodak, Rochester, NY) for the automated and selective determination of serum albumin, especially in stat-situations $(8,9)$. With these slides, serum albumin concentrations were reported to compare well with results obtained with liquid reagents of similar composition $(8,9)$. In the present study, we compared serum albumin concentrations determined with Ektachem slides on an Ektachem 700XR instrument (Eastman Kodak) with those obtained by serum protein electrophoresis on cellulose acetate (Olympus Hite 200, Hamburg, Germany) in a number of clinical situations, including nephrotic syndrome. In patient groups, where the albumin results from Ektachem and serum protein electrophoresis appeared not to be significantly correlated, albumin concentrations were also determined by immunonephelometry (Behring Nephelometer Analyser, Behring, Marburg, Germany). 


\section{Materials and Methods}

\section{Serum samples}

Blood was sampled from both ambulant and hospitalized patients, collected into dry commercial plastic tubes (Sarstedt, Essen, Belgium), centrifuged within $2 \mathrm{~h}$ after venipuncture, and in selected cases divided into aliquots (16). All but one aliquot were stored at $-20^{\circ} \mathrm{C}$ for subsequent immunonephelometric analysis of specific proteins. The remaining aliquot was kept at room temperature until assayed for serum protein by electrophoresis later on the same day. In neonates, blood was sampled from the umbilical cord.

\section{Protein assays}

Serum albumin and total protein were measured using the appropriate Ektachem slides on a Kodak Ektachem 700XR apparatus (Eastman Kodak). Serum protein electrophoresis on cellulose acetate was performed on an Olympus Hite 200 apparatus (Olympus) to separate serum albumin and $\alpha_{1}-, \alpha_{2}^{-}, \beta-$ and $\gamma$-globulin bands. These fractions were expressed in absolute concentration units $(\mathrm{g} / \mathrm{l})$, based on the total protein concentration determined on the Ektachem. In selected samples, circulating concentrations of albumin, $\alpha_{1}$-antiproteinase, $\alpha_{1}$-acid glycoprotein (orosomucoid), $\alpha_{2}$-macroglobulin and haptoglobin were determined by immunonephelometry on a Behring Nephelometer Analyser nephelometer (Behring) using commercial antisera from Behring (OSAL 14/15, OSAZ 08/09, OSAW 08/09, OSAM 08/09 and OSAV 14/15).

\section{Statistical analysis}

We used linear regression analysis (whenever $\mathrm{n} \geq 30$; $\mathrm{r}$ : Pearson correlation coefficient) and non-parametric Spearman rank correlation analysis (whenever $\mathrm{n}<30$; $\mathrm{r}_{\mathrm{s}}$ : Spearman rank correlation coefficient) to compare albumin concentrations determined with different methods and to test for statistical significance of correlations between (specific) protein concentrations on the one hand, and between-method differences in albumin on the other.

\section{Results}

Overall, albumin concentrations on the Ektachem correlated very significantly with data derived from serum protein electrophoresis on cellulose acetate (fig. 1). However, Ektachem values could be up to $16 \mathrm{~g} / 1$ higher than electrophoretic data on the Olympus Hite, especially in patients with nephrotic syndrome (up to 3 -times the value on the Olympus). Conversely, in other specimens, the results from the Olympus exceeded the Ektachem data by as much as $10 \mathrm{~g} / 1$ (corresponding to over $20 \%$ of the value on the Olympus). In 7 patients with nephrotic syndrome, albumin concentrations on the Ektachem (y) appeared not to be correlated with electrophoretically determined values $\left(\mathrm{y}=0.16 \mathrm{x}+19.1 ; \mathrm{r}_{\mathrm{s}}=0.22, \mathrm{~s}_{\mathrm{y}, \mathrm{x}}=2.3 \mathrm{~g} / \mathrm{l}\right.$; $P>0.05)$ and invariably exceeded the results from the Olympus by 20 to $200 \%$ (fig. 1, tab. 1). In these patients, electrophoretic data, but not the Ektachem results, were significantly correlated with albumin concentrations determined by immunonephelometry.

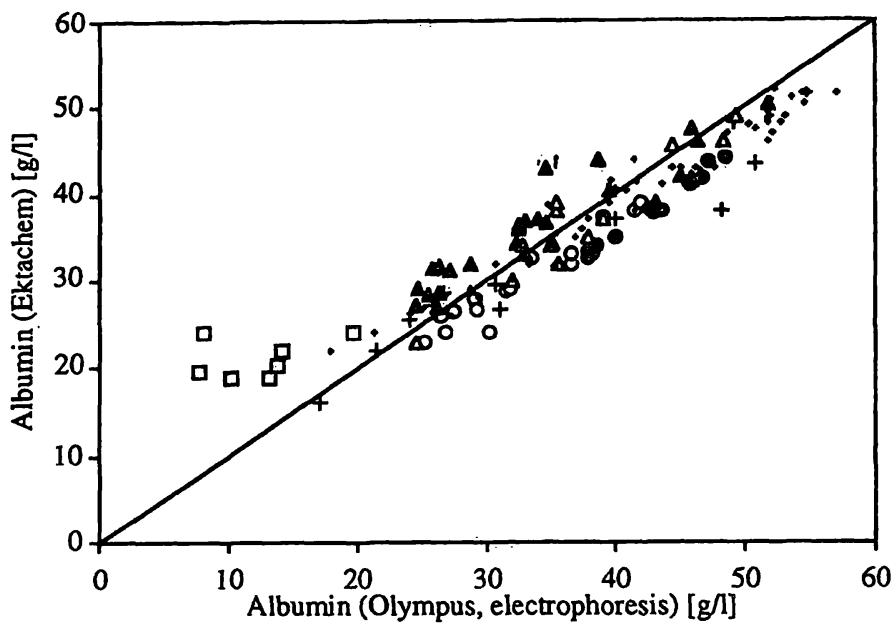

Fig. 1. Serum albumin concentrations on the Ektachem compared with results obtained by serum protein electrophoresis on the Olympus Hite 200.

ㅁ: nephrotic syndrome; O: liver disease; ๑: neonates; $+:$ intensive care patients; $\Delta: \mathrm{M}$-components; $\boldsymbol{\Delta}:$ inflammation; +: miscellaneous; $-: \mathrm{y}=\mathrm{x}$;

+ regression line for all samples $(n=140): y=0.76 x$ $+8.0 ; \mathrm{r}=0.95 ; P<0.0001 ; \mathrm{s}_{\mathrm{y} . \mathrm{x}}=2.8 \mathrm{~g} / \mathrm{l}$;

regression line with omission of patients with nephrotic syndrome $(\mathrm{n}=133): \mathrm{y}=0.82 \mathrm{x}+5.5 ; \mathrm{r}=0.95$; $P<0.0001 ; \mathrm{s}_{y_{\mathrm{i}} \mathrm{x}}=2.6 \mathrm{~g} / \mathrm{l}$.

Tab. 1. Serum albumin concentrations in 7 patients with nephrotic syndrome

\begin{tabular}{llll}
\hline Patient & \multicolumn{2}{l}{ Serum albumin $(\mathrm{g} / \mathrm{l})$} \\
\cline { 2 - 4 } & Ektachem & $\begin{array}{l}\text { Serum protein } \\
\text { electrophoresis }\end{array}$ & Nephelometry \\
& \multicolumn{2}{c}{${ }^{\mathrm{e}}$} & \\
\hline 1 & 19 & 10 & 6 \\
2 & 19 & 13 & 9 \\
3 & 24 & 8 & 5 \\
4 & 20 & 8 & 5 \\
5 & 24 & 20 & not done \\
6 & 20 & 14 & 9 \\
7 & 22 & 14 & 11 \\
\hline
\end{tabular}

${ }^{a}$ regression line of serum protein electrophoresis $(y)$ vs. nephelometry $(\mathrm{x}): \mathrm{y}=1.10 \mathrm{x}+2.95 ; \mathrm{r}_{\mathrm{s}}=0.96 ; \mathrm{s}_{\mathrm{y} . \mathrm{x}}=0.87 \mathrm{~g} / \mathrm{l}$; $P=0.03$;

regression line of Ektachem (y) vs nephelometry (x): $\mathrm{y}=-0.10 \mathrm{x}+21.4 ; \mathrm{r}_{\mathrm{s}}=-0.14 ; \mathrm{s}_{\mathrm{y}, \mathrm{x}}=2.2 \mathrm{~g} / \mathrm{l} ; P>0.05$.

At variance with the results in patients with nephrosis, albumin concentrations on the Ektachem and Olympus were significantly correlated in all other subject groups studied, namely 15 patients with chronic liver disease including cirrhosis $(\mathrm{y}=0.91 \mathrm{x}+0.1$; $\left.\mathrm{r}_{\mathrm{s}}=0.94 ; \mathrm{s}_{\mathrm{y}, \mathrm{x}}=1.5 \mathrm{~g} / \mathrm{l} ; P<0.0005\right) ; 12$ patients with monoclonal components (total number of bands = 13) migrating in the $\alpha_{2}, \beta$ - or $\gamma$-region (respectively 1 , 7 and 5 bands $)\left(\mathrm{y}=0.99 \mathrm{x}-0.3 ; \mathrm{r}_{\mathrm{s}}=0.84 ; \mathrm{s}_{\mathrm{y}, \mathrm{x}}=2.4\right.$ $\mathrm{g} / \mathrm{l} ; P<0.005) ; 12$ healthy neonates $(\mathrm{y}=1.06 \mathrm{x}-$ $\left.7.5 ; \mathrm{r}_{\mathrm{s}}=0.97 ; \mathrm{s}_{\mathrm{y}, \mathrm{x}}=0.5 \mathrm{~g} / \mathrm{l} ; P^{i}<0.001\right) ; 26$ patients with inflammation $\left(\mathrm{y}=0.76 \mathrm{x}+10.2 ; \mathrm{r}_{\mathrm{s}}=0.93\right.$; $\left.\mathrm{s}_{\mathrm{y}, \mathrm{x}}=2.4 \mathrm{~g} / \mathrm{l} ; P<0.0001\right) ; 11$ intensive care patients 


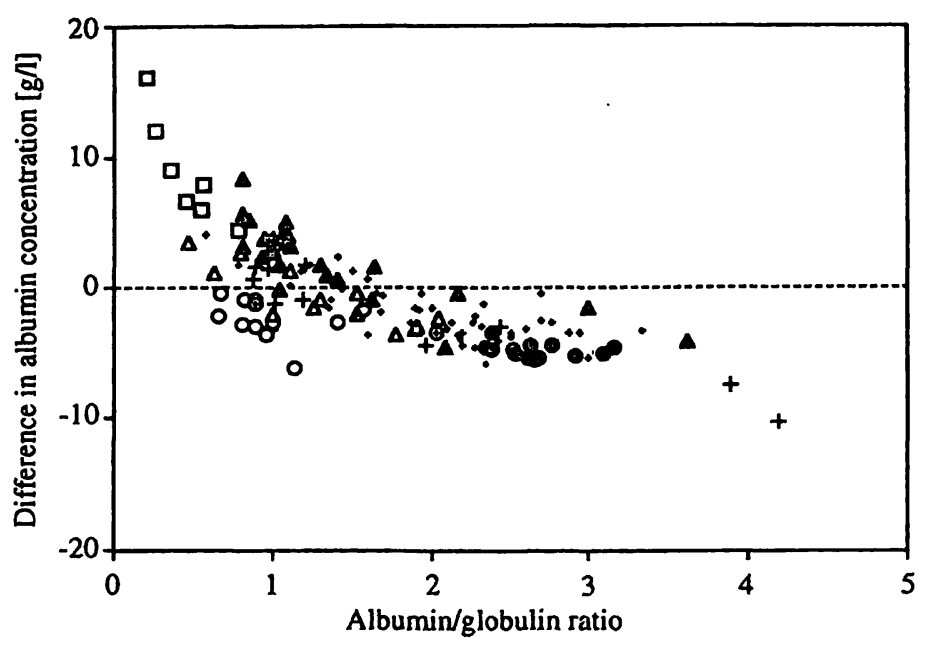

Fig. 2. Differences in serum albumin concentrations (Ektachem minus Olympus) as a function of albumin/globulin ratio in 140 patient samples.

ㅁ: nephrotic syndrome; o: liver disease; ๑: neonates; $+:$ intensive care patients; $\Delta: M$-components; $\Delta:$ inflammation; +: miscellaneous; $\cdots \cdot \mathrm{y}=0$.

on parenteral fluid therapy $(\mathrm{y}=0.77 \mathrm{x}+5.7$; $\left.\mathrm{r}_{\mathrm{S}}=0.94 ; \mathrm{s}_{\mathrm{y}, \mathrm{x}}=2.8 \mathrm{~g} / \mathrm{l} ; P<0.003\right)$ and 57 patients suffering from miscellaneous diseases $(\mathrm{y}=0.82 \mathrm{x}$ $\left.+5.9 ; \mathrm{r}=0.98 ; \mathrm{s}_{\mathrm{y} \cdot \mathrm{x}}=1.7 \mathrm{~g} / \mathrm{l} ; P<0.0001\right)$.

As is apparent from figures 1 and 2, Ektachem slides yielded invariably higher albumin concentrations than serum protein electrophoresis in patients with nephrotic syndrome. This systematic positive bias was not observed in patients with chronic liver disease where albumin and albumin/globulin ratios also tend to be low, or in patients with monoclonal components and low albumin/globulin ratios. Ektachem values often surpassed electrophoretically determined albumin concentrations in patients with inflammation. In contrast, albumin values on the Ektachem were lower than those determined by serum protein electrophoresis in the blood of newborns with low globulin concentrations, and in certain intensive care patients receiving parenteral fluids. In 2 patients with bisalbuminaemia, total albumin concentration, obtained by integration of the two separate albumin bands, differed by less than $2 \mathrm{~g} / 1$ from the Ektachem result (not shown).

When considering all 140 samples tested, betweenmethod differences (Ektachem minus Olympus) in albumin (y) were inversely correlated, albeit weakly, with total protein concentration, more strongly with the albumin concentration, and highly significantly with the albumin/globulin ratio (tab. 2). The latter dependency appeared primarily associated with elevated $\alpha_{1}$ - or $\alpha_{2}$-globulin concentrations, since betweenmethod differences were only weakly related to $\beta$ globulin concentrations and not at all to $\gamma$-globulins, but very significantly correlated to $\alpha_{1}$ - and $\alpha_{2}$-globulin concentrations, and even more so to the summation of both (tab. 2). Correlation with $\beta$-globulin concentrations clearly improved when sera with monoclonal components (several having $\beta$-mobility) were omitted from the correlation analysis.

In a selected group of 26 samples with sufficient residual serum volume, the main protein constituents of the $\alpha_{1}$-globulins $\left(\alpha_{1}\right.$-antiproteinase and $\alpha_{1}$-acid glycoprotein) and of the $\alpha_{2}$-globulins ( $\alpha_{2}$-macroglobulin and haptoglobin) were quantified by immunonephelometry. Correlations were then sought between the between-method differences in albumin concentration (Ektachem minus Olympus) and (combinations of) these specific protein concentrations (tab. 3). The tightest correlation was obtained with proteins with $\alpha_{2}$-mobility, especially haptoglobin. Correlation with individual $\alpha_{1}$-proteins was not significant, but combination of haptoglobin concentrations with $\alpha_{2}$-macroglobulin slightly improved the values for $r_{s}$ and $s_{y, x}$. Inclusion of $\alpha_{1}$-proteins had little or no effect, although there existed a weak but significant correlation with the sum of $\alpha_{1}$-antiproteinase and $\alpha_{1}$-acid glyco-

Tab. 2. Linear regression analysis of between-method differences in serum albumin concentration ( $\mathrm{g} / \mathrm{l}$ ) as a function of total protein or protein fractions determined by serum protein electrophoresis in 140 patient sera.

\begin{tabular}{|c|c|c|c|c|c|}
\hline $\begin{array}{l}\mathrm{x} \\
\mathrm{g} / \mathrm{l}^{\mathrm{b}}\end{array}$ & Slope & Intercept & $\mathbf{r}$ & $P$ & $\begin{array}{l}s_{y, x} \\
g / 1^{t}\end{array}$ \\
\hline Total protein & -0.08 & 4.06 & -0.25 & $<0.001$ & 3.7 \\
\hline Albumin & -0.23 & 7.92 & -0.68 & $<0.0001$ & 2.8 \\
\hline Albumin/globulin ratio & -3.57 & 5.11 & -0.75 & $<0.0001$ & 2.5 \\
\hline$\alpha_{1}$-Globulins & 2.54 & -5.96 & 0.66 & $<0.0001$ & 2.9 \\
\hline$\alpha_{2}$-Globulins & 0.91 & -6.23 & 0.81 & $<0.0001$ & 2.3 \\
\hline$\beta$-Globulins & 0.18 & -1.95 & $0.20^{c}$ & $<0.02^{c}$ & 3.8 \\
\hline$\gamma$-Globulins & 0.01 & -0.93 & 0.02 & $>0.05^{d}$ & 3.9 \\
\hline$\alpha_{1}+\alpha_{2}$-Globulins & 0.82 & -7.40 & 0.86 & $<0.0001$ & 2.0 \\
\hline
\end{tabular}

a $=$ (albumin on Ektachem) - (albumin on Olympus)

b/l except for albumin/globulin ratio

c $\mathrm{r}=0.41$ and $P<0.0001$ after omission of 12 samples with an M-component

d not significant 
Tab. 3. Spearman rank correlation analysis of between-method differences in serum albumin concentration ${ }^{\mathrm{a}}(\mathrm{g} / \mathrm{l})$ as a function of specific protein concentrations determined by immunonephelometry in 26 patient sera ${ }^{b}$

\begin{tabular}{|c|c|c|c|c|c|}
\hline $\begin{array}{l}x \\
g / 1\end{array}$ & Slope & Intercept & $r_{s}$ & $P$ & $\begin{array}{l}s_{y, x} \\
g / 1\end{array}$ \\
\hline $\begin{array}{l}\alpha_{1} \text {-Antiproteinase (1) } \\
\alpha_{1} \text {-Acid glycoprotein (2) } \\
\alpha_{2} \text {-Macroglobulin (3) } \\
\text { Haptoglobin (4) } \\
\text { Sum of (1) and (2) } \\
\text { Sum of (3) and (4) } \\
\text { Sum of (1), (2). (3) and (4) } \\
\text { Sum of (1), (3) and (4) }\end{array}$ & $\begin{array}{l}1.19 \\
2.34 \\
1.70 \\
2.88 \\
0.96 \\
1.50 \\
1.23 \\
1.30\end{array}$ & $\begin{array}{l}-2.47 \\
-0.99 \\
-4.22 \\
-4.98 \\
-2.56 \\
-6.60 \\
-9.43 \\
-9.07\end{array}$ & $\begin{array}{l}0.36 \\
0.19 \\
0.58 \\
0.75 \\
0.40 \\
0.81 \\
0.79 \\
0.79\end{array}$ & $\begin{aligned} & 0.07^{c} \\
& 0.33^{c} \\
< & 0.004 \\
< & 0.0001 \\
< & 0.05 \\
< & 0.0001 \\
< & 0.0001 \\
< & 0.0001\end{aligned}$ & $\begin{array}{l}6.1 \\
6.3 \\
4.8 \\
3.3 \\
6.1 \\
2.9 \\
2.9 \\
2.8\end{array}$ \\
\hline
\end{tabular}

y $=$ (albumin on Ektachem) - (albumin on Olympus)

b for comparison: when $\mathrm{x}=$ sum of $\alpha_{1}$ - and $\alpha_{2}$-globulins by serum protein electrophoresis $(\mathrm{g} / \mathrm{l})$, slope $=0.94$, intercept $=-7.62$, $\left.\mathrm{r}_{\mathrm{s}}=0.92, P<0.0001, \mathrm{~s}_{\mathrm{y} \mathrm{x}}=2.3 \mathrm{~g} / \mathrm{l}\right)$

c not significant whenever $P>0.05$

protein concentrations. However, none of the combination of specific proteins yielded better correlations than that observed for the integrated value of $\alpha_{1}$ - or $\alpha_{2}$-globulins obtained by serum protein electrophoresis on the same specimens.

\section{Discussion}

The present report confirms that for unselected patient samples, serum albumin concentrations obtained with bromcresol green-containing Ektachem slides are overall significantly correlated with results obtained electrophoretically $(8,9,17)$. However, large betweenmethod differences, ranging from $10 \mathrm{~g} / \mathrm{l}$ lower to 16 $\mathrm{g} / \mathrm{l}$ higher on the Ektachem, were noted in individual samples. In patients with nephrotic syndrome, where albumin concentrations are very low and their accurate monitoring is mandatory (18), Ektachem slides constantly overestimated serum albumin, compared with serum protein electrophoresis and immunonephelometry. This occurred to such an extent (as much as $300 \%$ of the Olympus value) that Ektachem data were no longer correlated to electrophoretic or immunonephelometric results, precluding the use of these slides for the diagnosis and monitoring of patients with nephrosis. Serum concentrations of $\alpha_{1}$ and, especially, $\alpha_{2}$-globulins were most closely correlated to the overestimation of albumin on the Ektachem. In nephrosis, increased synthesis of albumin and globulins by the liver tend to counteract urinary albumin losses, thereby creating an inverse relationship between serum albumin and $\alpha$-globulins (18). This might explain why, on the Ektachem, albumin tends to level off between 19 and $24 \mathrm{~g} / \mathrm{l}$, independently of the true albumin content in patients with nephrotic syndrome.

In various other clinical situations, albumin concentrations on the Ektachem and Olympus differed less than for nephrotic patients. Overall, the amplitude and direction of these differences were related to the albumin/globulin ratio and this association, in turn, was primarily determined by the amount of $\alpha$-globulins, in particular $\alpha_{2}$-globulins. Consequently, higher Ektachem values were noted in patients with e.g. acute phase reactions (up to $8.5 \mathrm{~g} / \mathrm{l}$ ), whereas relatively lower results were observed in sera with low $\alpha$-globulin concentrations, e. g. in umbilical cord blood specimens or in samples from intensive care-patients receiving large volumes of parenteral fluids. By testing patients with increased circulating concentrations of monoclonal or polyclonal immunoglobulins (gammopathies, liver disease), it was verified that these protein fractions did not correlate significantly with between-method differences in albumin, despite the frequent presence of low albumin/globulin ratios and hypoalbuminaemia (18). Since the Ektachem did not show a positive bias for albumin in the analysis of samples with low albumin and high $\gamma$-globulin concentrations from patients with liver disease, it does not seem that hypoalbuminaemia or the albumin/ globulin ratio per se are responsible for betweenmethod differences in albumin concentration (17). The correlation between albumin concentrations and between-method differences in albumin therefore probably stems from the association of low albumin values with increased globulin fractions in certain pathological situations such as nephrosis.

Specific protein determination with immunonephelometry confirmed that the integration of the main protein components forming the $\alpha_{1}$ - and $\alpha_{2}$-globulin band is more closely associated with the betweenmethod differences in albumin, rather than acute phase reactants strictu sensu. Indeed, $\alpha_{2}$-macroglobulin clearly contributed to these differences, yet it is not considered an acute phase protein (18). Conversely, $\alpha_{1}$-acid glycoprotein is a well established acute 
phase reactant; yet its concentration did not closely parallel the observed between-method differences. In contrast, the latter differences were very tightly correlated with circulating haptoglobin concentrations. Although such correlations might suggest a positive interference of haptoglobin or other $\alpha$-globulins in the Ektachem assay, they do not support the existence of a causal relationship. It is furthermore possible that increased concentrations of certain $\beta$-globulins that were not assayed in this study, such as transferrin, or overproduction of lipoproteins by the liver in nephrotic syndrome (18), might also play a role in the observed differences (19).

Taking into account that Ponceau red, or other dyes used in serum protein electrophoresis, display variable binding affinity depending on the type of protein (18), and that immunonephelometric measurements can suffer from non-specific reactions (9), it is obvious that both comparison methods can also contribute to the observed overall between-method differences in albumin. It therefore seems reasonable to assume that these differences are small enough, and that the cor-

\section{References}

1. Rodkey, F. L. (1964) Binding of Bromcresol Green by Human Serum Albumin. Arch. Biochem. Biophys. 108, $510-516$.

2. Doumas, B. T., Watson, W. A. \& Biggs, H. G. (1971) Albumin Standards and the Measurement of Serum Albumin with Bromcresol Green. Clin. Chim. Acta 31, $87-96$.

3. Doumas, B. T. \& Biggs, H. G. (1972) Determination of Serum Albumin. Stand. Methods Clin. Chem. 7, 175-188.

4. Pinnell, A. E. \& Northam, B. E. (1978) New Automated Dye-binding Method for Serum Albumin Determination with Bromcresol Purple. Clin. Chem. 24, 80-86.

5. Gustafsson, J. E. C. (1976) Improved Specificity of Serum Albumin Determination and Estimation of "Acute Phase Reactants" by Use of the Bromcresol Green Reaction. Clin. Chem. 22, 616-622.

6. Savory, J., Heintges, M. G., Sonowane, M. \& Cross, R. E. (1976) Measurement of Total Protein and Albumin in Serum with a Centrifugal Analyzer. Clin. Chem. 22, 11021104.

7. Duggan, J. \& Duggan, P. F. (1982) Albumin by Bromcresol Green. A Case of Laboratory Conservatism. Clin. Chem. 28, 1407-1408.

8. Buffone, G. J., De Armas, W., Framley, V., Ou, C. N. \& Schimbor, C. (1984) Multilayer-Film Bromcresol Green Method for Albumin Measurement Compared with Three Others. Clin. Chem. 30, 581-582.

9. Geen, R. J., Day, B. S. \& Powers, D. M. (1991) Multilayerfilm Bromcresol Green Method for Albumin Measurement Significantly Inaccurate when Albumin/Globulin Ratio is $<0.8$. [Response to letter] Clin. Chem. 37, 767-768.

10. Maguire, G. A. \& Price, L. P. (1986) Bromcresol Purple Method for Serum Albumin Gives Falsely Low Values in Patients with Renal Insufficiency. Clin. Chim. Acta 155, $83-88$. relation between the Ektachem and Olympus is sufficient to allow the use of the Ektachem slides for serum albumin assay in most clinical situations, with the exception of patients with nephrosis or any other condition asssociated with very high concentrations of $\alpha$-globulins (other than immunoglobulins). Reducing the time at which colour formation is read in the Ektachem instrument might improve the specificity of the assay. However, it is not obvious that experimental data on early readings obtained with liquid reagents $(12-15)$ can be extrapolated as such to multilayer film elements of similar composition, where the time needed for diffusion of serum or back-diffusion of reagents into adjacent layers has also to be taken into account.

\section{Acknowledgements}

We are endebted to $N$. Ringoot and $L$. Vermeir for excellent secretarial help and to L. De Pree, S. Exterbille, P. Goubert, F. Lebleu and $E$. Verkest for outstanding technical assistance. $C$. De Grove, K. Putteman and P. Van Looy (Clinical Products Division, Eastman Kodak, Belgium) kindly provided product information.
11. Bush, V. \& Reed, R. G. (1987) Bromcresol Purple Dyebinding Methods Underestimate Albumin that is Carrying Covalently Bound Bilirubin. Clin. Chem. 33, 821-823.

12. Websier, D. (1977) The Immediate Reaction between Bromcresol Green and Serum as a Measure of Albumin Content. Clin. Chem. 23, 663-665.

13. Speicher, C. E., Widish, J. R., Gaudot, F. J. \& Hepler, B. R. (1976) An Evaluation of the Overestimation of Serum Albumin by Bromcresol Green. Am. J. Clin. Pathol. 69, $347-350$.

14. Gustafsson, J. E. C. (1978) Automated Serum Albumin Determination by Use of the Immediate Reaction with Bromcresol Green Reagent. Clin. Chem. 24, 369-373.

15. Plesher, C. J. (1978) Continuous Flow Analysis for Serum Albumin, by Use of the Immediate Reaction with Bromcresol Green. Clin. Chem. 24, 2036-2039.

16. Gorus, F., Claessens, V., Goubert, P. \& Laureys, M. (1988) A Sensitive Bioluminescent Immunoinhibition Test for CKB Subunit Activity and a CK-MB Specific ELISA Compared : Correlation with Agarose Electrophoresis and Influence of CK-Isoenzyme Profile on Results. Clin. Chem. $34,1474-1478$.

17. Leerinck, C. B. \& Winckers, E. K. A. (1991) MultilayerFilm Bromcresol Green Method for Albumin Measurement Significantly Inaccurate when Albumin/Globulin Ratio is $<0.8$ [Letter]. Clin. Chem. 37, 766-767.

18. Silverman, L. M., Christenson, R. H. \& Grant, G. H. (1986) Aminoacids and Proteins. In: Textbook of Clinical Chemistry', 1st ed. (Tietz, N. W., ed.) pp. 519-618. W. B. Saunders Company, Philadelphia.

19. Webster, D. (1979) A Study of the Interaction of Bromcresol Green with Isolated Serum Globulin Fractions. Clin. Chim. Acta 53, 109-115.

Frans K. Gorus, M. D., Ph. D.

Laboratorium Klinische Chemie

Akademisch Ziekenhuis Vrije Universiteit Brussel 101 Laarbeeklaan

B-1090 Brussels

Belgium 
